\author{
ERIK HAGASETH HAUG, TRISTRAM HOOLEY, \\ JAANA KETTUNEN AND RIE THOMSEN
}

\title{
1. SETTING NORDIC CAREER GUIDANCE IN CONTEXT
}

\begin{abstract}
The introduction to this volume discusses the importance of situating career and career guidance in context. It makes a connection to wider research and writing that challenges the idea that career theory can be global and universal and argues that there is a need for attention to local context and culture. It then moves on to set the scene for a volume focusing on the Nordic countries, by defining the 'Nordic' and exploring key features of the region including the Nordic welfare model and the history of collaborations in career guidance across the region. It proposes the four 'COs' of Nordic career guidance (context, community, co-construction and collaboration) before outlining the structure of the volume and looking to the future.
\end{abstract}

\section{INTRODUCTION}

The concept of 'career' is a powerful one when we are seeking to understand societies and how people live in them. Career describes individuals' paths through life, learning and work, it describes how the individual interfaces with social institutions including the education system, employers, civil society and the state. Because our careers are socially and culturally embedded it matters where they are enacted. This book will explore what kind of context the Nordic region offers for the pursuit of career, how the development of careers are supported in welfare societies and how career guidance is enacted in this context.

The book adopts a democratic definition of career. It argues that everyone has a career and contests definitions of career which are hierarchical, linear and exclusively focused on paid work. Careers can be pursued in many ways, both consciously and unconsciously, but careers can only happen in a context. In this sense the concept of 'career' is a tool of psycho-social analysis. It helps us to understand how individuals interact with society, how they engage with and move between institutions and how such relationships are integrated into identity as well how they influence the sociopolitical context.

Such a theoretical definition of career might not be immediately recognisable to the average citizen of Oslo, Odense or Oulu. As Bakke (Chapter 2) describes, the 
concept of career has a chequered history within the Nordic realm. Career can be seen as being infused with individualistic, hierarchical and neoliberal attitudes (Hooley, Sultana, \& Thomsen, 2018) that are troubling to the Nordic self-image. Climbing the career ladder, especially if you leave others on the ground as you ascend, does not seem very Nordic. The satirical Jante's law (Sandemose, 1999[1933], p. 66), which is supposed to characterise the Nordic relationship between the individual and the community begins with 'you shall not believe that you are anything' and goes on to command that 'you shall not believe you are good for anything'. While many have critiqued how far Jante's law provides a viable summary of Nordic culture (e.g. Trotter, 2015) it is clear that some Nordic values (egalitarianism, collectivity and a moral and political commitment to the welfare state) sit in tension with ideas of career as a project of the self (Grey, 1994) and individuals as aspirational and agentic 'life designers' (Savickas, 2012).

The concept of career does not have a single and all-encompassing definition. Rather it functions as what Bergmo-Prvulovic (2018, p. 151) describes as a 'bridging object framed by conflicting perspectives'. The contributors to this volume all bring their definitions of career. They also describe how policy makers in the Nordic countries bring alternative definitions, educators and career professionals bring other perspectives and citizens still more. In this blizzard of contestation the current volume will seek to explore the value of thinking about career more overtly within a Nordic context, both in theoretical terms and through the social practice of career guidance.

\section{Defining Career Guidance}

Career guidance describes a wide body of educational, counselling and active labour market interventions which seek to support individuals with their careers. While such activities adopt various terminologies in different countries (career counselling, career education, career development, work-related learning and so on), a recognisable body of policy and practice can be found in this area across the world (e.g. OECD, 2004; Watts, 2014; Zelloth, 2009). Within the five Nordic countries there is a strong tradition of career guidance which the current volume will address and explore. In terms of research in career guidance, the Nordic countries have followed slightly different, yet complimentary paths (Plant, 2003). The balance between studies in guidance based on sociology, psychology, and even ethnology and philosophy varies according to the research focus and tradition of each of the Nordic countries (e.g. Haug et al., 2019b; Plant, 2003).

In the Nordic languages, different terms are used to describe the concept of career guidance. These include karrierabágádallan (Sami), uraohjaus, urasuunnittelun ohjaus, opinto-ohjaus, oppilaanohjaus (Finland), náms- og starfsráðgjöf (Iceland) and aqqutissiuussineq (Greenland). Furthermore, the word veiledning (Norwegian), vägledning (Swedish), vejledning (Danish) or vegleiðing (Faroese) is similar across much of the region with the etymology of the word meaning 'leading the way'. 
A recent article (Haug et al., 2019b) argues that the understanding of career guidance found in the research literature from the Nordic countries between 2003 and 2016 broadly coincides with the definition of educational and vocational guidance stated in the European Lifelong Guidance Policy Network (ELGPN) Glossary (2014). There, educational guidance is defined as 'helping an individual to reflect on personal educational issues and experiences and to make appropriate educational choices', and vocational guidance is defined as 'help for individuals to make choices about education, training and employment' (ELGPN, 2014).

Until recently career guidance in the Nordic countries has been concerned with supporting people to make career decisions, but there has been a continuing and increasing focus on what citizens learn from taking part in career guidance and career education.

The ELGPN definition (2014) builds on a variety of definitions of career guidance that have been proposed in the theoretical and policy literature. In this volume we have utilised Hooley et al.'s (2018, p. 20) definition because it foregrounds the social and collective aspects of career guidance in a way that aligns well with the way that the field has developed in the Nordic countries.

Career guidance supports individuals and groups to discover more about work, leisure and learning and to consider their place in the world and plan for their future. Key to this is developing individual and community capacity to analyse and problematiise assumptions and power relations, to network and build solidarity and to create new and shared opportunities. It empowers individuals and groups to struggle within the world as it is and to imagine the world as it could be.

Career guidance can take a wide range of forms and draws on diverse theoretical traditions. But at its heart it is a purposeful learning opportunity which supports individuals and groups to consider and reconsider work, leisure and learning in the light of new information and experiences and to take both individual and collective action as a result of this.

As we will see in this volume, within the Nordic countries career guidance takes many forms and is addressed to many different groups. This includes young people, those in work, facing unemployment, moving in and out of education, refugees and those moving into retirement. The volume will also explore the relationship between policy and practice and how this is central to the nature of Nordic career guidance.

\section{Putting Career and Career Guidance in Context}

Most research on career guidance does not explicitly locate itself geographically (Alexander \& Hooley, 2018). Career theories are often advanced as universally applicable. However, such claims to universality have been challenged from a variety of perspectives including the geographical (e.g. Alexander, 2018; Thomsen, 2012), the cultural (e.g. Arulmani, 2016; Sultana, 2017b) and the epistemic (Haug, 
Chapter 14; Ribeiro \& Fonçatti, 2018). Such critiques highlight the differences between places, cultures and ways of knowing and observe that the experience of developing one's career, or of helping others to develop their career is not the same for everyone and in every place. Given this, we should view the globalist, universalising urges within career theory sceptically.

Sultana (2017a) responded to these challenges with the publication of Career guidance and livelihood planning across the Mediterranean. In this he explores how career guidance 'acquires diverse meanings in different cultures, institutional traditions, and economic realities' (Sultana, 2017a, p. 4). Sultana takes the Mediterranean as his focus, exploring how career guidance shifts and changes across the countries around and adjacent to the Mediterranean. He argues that the context is important both in coming up with a meaningful understanding of how people experience their careers, and in creating forms of career guidance that are meaningful and relevant within the context.

Sultana (2017a) and the other authors in his volume on the Mediterranean demonstrate that career guidance is not a fixed thing that sits unproblematically in a context. Rather as it travels across national boundaries it acts upon and is acted upon by the context that it travels to. In some cases, it arrives as a form of soft power seeking to transform systems and subjectivities into forms that are favourable to those who are introducing career guidance (see Kjærgård, Chapter 6). Plant and Thomsen (2011) have referred to this as social control in a velvet glove in their discussion of the development of the Danish youth career guidance system. In others, it is reimagined within the new context and transformed into something locally relevant. Elsewhere Ribeiro and Fonçatti (2018) have described this process of the cultural integration of career guidance as recognising the interplay between globally and locally produced ways of thinking. On one hand there are top-down 'globalised localisms' which take a local phenomenon, such as career guidance, and impose it in contexts across the globe. On the other hand, there are bottom up 'localised globalisms' which rethink and remake phenomenon in ways that fit with the local context. Sultana's work (2017a) on the Mediterranean shows that both of these processes are evident.

The growing tradition of writing that is foregrounding context, is suggestive of a major new paradigm for research in career guidance, which the current volume responds to. We need to move away from viewing career guidance as a global universal and focus on how it interacts with specific contexts, cultures, places and people. In response to this we offer a volume that explores these issues from the perspective of our context in the Nordic states. We hope that others will pick up this project and propose future volumes and studies that address other parts of the world. However, this should not be viewed as a project which will be finished once we all have a bookshelf complete with a series of books on Career guidance in ... South East Asia ... Australasia ... Central America and so on. Rather we seek to support a paradigm shift which changes the way in which we see what career is, how it is enacted and reshapes what career guidance is understood to be. The focus on context 
requires us to view career and career guidance as embedded practices, to recognise and report on the geographic, cultural, political and organisational context in which they are found, to acknowledge that people interact with career guidance and that this interaction changes the nature of practice and to embrace the need to localise our theories and thinking.

This volume is a contribution to this broader paradigmatic shift. In it we bring together discussions about career and career guidance that take place in the Nordic countries. We have encouraged authors to view their contributions within this specifically Nordic framing and to explore how the phenomenon that they are describing interact with the Nordic. Given this it is important to now explore what is meant by the term 'Nordic' and to consider how well that can serve as a summary of the context within which career guidance operates in this part of the world.

\section{DEFINING THE NORDIC}

At its most basic 'Nordic' is a geographical category that describes an area in Northern Europe and the Northern Atlantic comprising Denmark, Sweden, and Norway as well as Finland to the east and Iceland in the Atlantic. The Nordic region also includes the self-governing areas of Åland, Greenland and the Faroe Islands. The region is the home of two indigenous people; the Greelandic Inuits and the Sami in the Northern parts of Finland, Sweden and Norway. Linguistically, Swedish, Norweigian, Danish, Faroese and Icelandic have a common term "Norden", "Norður" (the North) for the region that reinforces the geographical basis of the region and highlights its position within global geography.

The association of different countries and areas with the Nordic is an historical category which describes the inter-related histories of the countries which are categorised by various forms of conquest, union and federation as well as looser forms of treaty, partnership and co-operation (Archer \& Joenniemi, 2017; Tägil, 1995).

In addition to, and as a result of, the geographical and historical components that comprise the Nordic, the countries in the region also share a number of cultural features including shared folklore and folk history, Protestantism, linguistic similarities (excepting Finish, Greenlandic/Kalaallisut and the Sami languages), leisure activities especially out-door and physical activities (e.g. walking and skiing) and cultural values e.g. egalitarianism and collectivism (Gradén, 2016; Grendstad, 2001).

The region also shares political institutions, most notably the Nordic council formed in 1952 and the Nordic council of ministers formed in 1971, which formalise the Nordic into a political relationship (Strang, 2015). In addition, the Sámi Parliamentary Council (SPC) founded in 2000 provides another fora for crossborder co-operation which brings together the Sámi parliaments in Finland, Norway and Sweden. These political arrangements are echoed in multiple forms of crossNordic collaboration that exist across a wide variety of policy areas. 
These forms of cross-border collaboration are underpinned by similar, although far from identical political systems and ideologies. The ideological similarity of what is sometimes referred to as the 'Nordic model' eases collaboration across the region as it creates a situation where there are similar institutions and approaches to policy across different countries. Key features of the 'Nordic model' include mixed economies, social democratic politics, high levels of taxation, welfare provision and a commitment to gender equality, social cohesion and limiting income inequality and differences between social classes (Marklund, 2017; Ryner, 2007).

It is important to recognise the multi-faceted way in which the category of the Nordic is comprised as the geographical, historical, cultural, political and ideological elements all interact in both explicit and implicit ways. Various writers have argued that the idea of the Nordic has emerged in a purposeful way which serves the aims of both internal social cohesion and the development of soft power in the world (Browning, 2007; Marklund, 2017). The concept of Nordic 'exceptionalism' has its origins in nineteenth century nationalism but became globally important during the Cold War. At that time the idea that the Nordic countries were different from the rest of the world (supporting peace and internationalism, bridging East and West whilst supporting the global South, and taking a middle way between capitalism and communism) could all be viewed as a claim to greater rationality and the idea that these states were better than the rest of the world and offered a model that others should follow (Browning, 2007). The idea of Nordic 'exceptionalism' therefore makes use of both meanings of the word (both 'different from' and 'better than').

Hvid and Falkum (2019) quote the Deputy Director of Employment, Labour and Social Affairs at the Organisation for Economic Co-operation and Development (OECD) who said 'Whether you look at unemployment, employment, income, equality, social security, or the quality of the working environment, the Nordic countries are at the top of the international rankings'. This means that other states, national administrations and global organisations are interested in examining the different elements of the Nordic model in detail (e.g. Hooley, Chapter 3). This book considers career guidance as an important element of the Nordic model and gives a rich and detailed insight into the different approaches, practices, tools, systems and more conceptual ways of thinking about career and career guidance that can be found in the Nordic countries.

Since the Cold War, Nordic exceptionalism has had to be remade to take account of the loss of the Cold War context; the increasing neoliberalisation of the Nordic model; and the challenge to the region's progressive liberalism that has come from growth of the populist right (Dahl, 2012; Jungar \& Jupskås, 2014; Mjøset, 2011). This new brand of 'Nordicity' retains political components but is also strongly cultural in nature. Andersen, Kjeldgaard, Lindberg and Östberg (2019) argue that it is characterised by a 'complex brandscape' (p. 214) comprised of a series of carefully balanced tensions such as: modernity/Norse mythology; egalitarian inclusiveness/ luxury designer brands; gendered fashion/gender reflexivity and equality; and 
ethnocentrism/multi-culturalism. But, as Marklund's (2017) discussion of the representation of the Nordic in Monocle magazine demonstrates, the collection of, at times contradictory, images that comprise this supra-national brand remain highly seductive internationally. In this sense Nordicity has become an ambiguous but still powerful and positive signifier. The Nordic is desirable, it suggests much, but it can be difficult to pin down.

Despite their many similarities it is important to recognise that there are big differences between the different Nordic states and areas. While there is much that unites the region, it is far from homogeneous. The Nordic region includes large cosmopolitan cities as well as some of the most remote and isolated areas on the planet. Some states have benefitted from access to valuable natural resources, while others have not. The region is becoming increasingly ethnically diverse, although the extent of such diversity varies by state. States have also taken different positions on key geopolitical issues including membership of the European Union and the North Atlantic Treaty Organisation (NATO). Politically, social democracy has remained dominant in Sweden whilst most of the rest of the Nordic states have experienced a range of right-wing governments. We will explore this diversity further throughout the volume.

\section{THE NORDIC WELFARE MODEL}

The Nordic Welfare model describes both a particular set of policies and an abstract ideal. While it is enacted differently across the Nordic region authors also agree on its similarities. Most prominently is a high level of public spending on welfare which offers citizens a range of benefits including low cost full time professional day-care, free primary, secondary and tertiary education, free health insurance, subsidised dental care, and low cost elder-care. A key principle of these systems is that of universalism, meaning that in theory at least, all citizens can access all services (Greve, 2007). Greve (2007, p. 45) labels this 'the Scandinavian, Socialdemocratic, Keynesian model' noting that in this system the state is largely responsible for organising and financing the welfare state.

The Nordic model describes an approach to government that goes beyond the provision of generous universal benefits. Another key feature is the system of collective bargaining covering most of the private as well as the public labour market (Nielson, 2016). This is accompanied by a system of voluntary unemployment insurance run by the trade unions but subsidised by the state with a relatively high level of unemployment benefits (the so-called flexicurity system) which is designed to compensates for the absence of strong job security for individual employees. The Nordic model enables a high level of labour market mobility to be combined with a high level of employment (including high levels of employment for women and young people) (Greve, 2007; Nielson, 2016). A key desired outcome from the welfare system is the engagement of the populace with work and the development of human capital (see Bakke, Chapter 2). 
Career guidance sits in the middle of several key elements of the Nordic welfare state. It lives within the public employment services where it is asked to support individuals to maximise their employability and remain within the labour market. Since the 1990s, these services have increasingly adopted 'active labour market policy' shifting the focus from the provision of welfare to unemployed people and towards conditional 'workfare' policies which link labour market participation to the entitlement to benefits (Kvist \& Grace, 2011). Integrating career guidance into such active labour market policies can be problematic as it requires careers professionals to balance the development aspirations of the field with the elements of compulsion and social control (Darmon \& Perez, 2011).

Career guidance is also central to youth services and particularly to services that seek to reengage young people in education and training who are currently not working or studying. As has already been discussed the Nordic model places a high value on labour market participation and consequently includes public services to ensure that young people experience a smooth transition from education to the labour market (Halvorsen \& Hvinden, 2015). The increasing focus on active labour market policy as a key component of the Nordic model extends to young people through the delivery of services, including career guidance, which are designed to channel young people back into the labour market through guidance, education and training.

Finally, it is important to recognise that the Nordic education system is at the centre of the Nordic welfare model (Antikainen, 2006; Prøitz \& Aasen, 2017). As this book will show career guidance is deeply embedded into the Nordic education system and serves a number of key functions including helping individuals to manage their way around the system and facilitating their transition into work.

\section{CAREER GUIDANCE AND COLLABORATION IN THE NORDIC COUNTRIES}

The Nordic countries have a long history of collaborating on career guidance practice and policies. There has also been cross-Nordic collaboration between academic programmes with responsibility for training career professionals and in relation to research and evidence in the field.

The Nordic career guidance associations have organised themselves in Nordiska förbundet för studie- och yrkesvägledning [the Nordic Union for Study and Career Guidance] (NFSY). This body allows for the sharing of challenges and insights among the Nordic countries.

The Nordic Council of Ministers has played an important role in establishing and financing cross national collaboration, networks and projects in the field of career guidance. Nordiskt nätverk för vuxnas lärande [the Nordic Network for Adult Learning] (NVL) was established in 2005 by the Nordic Council of Ministers who continue to finance the network. NVL has hosted a thematic group on adult career guidance. This group aims to put the development of career competences for adults on the agenda and support meaningful transition in education and work. NVL has published reports on various aspects of career guidance in the Nordic countries. 
These include papers discussing expected outputs/outcomes of guidance services for adults in the Nordic countries (Vuorinen \& Leino, 2009), career guidance and the validation of prior learning (NVL, 2015); the coordination of guidance provision across the region (NVL, 2017); and, in collaboration with the ELGPN, a paper focusing on Career Management Skills (CMS) and exploring their value to the Nordic countries (Thomsen, 2014).

Another network supported by the Nordic Council of Ministers through Nordplus is VALA which is a network of career counselling and guidance programs at higher education institutions in the Nordic and Baltic countries. The aim of VALA is to increase professionalisation and strengthen ties and co-operation between higher education institutions offering academic education in career guidance. VALA supports student and teacher mobility and hosts a summer school in ICT and guidance at the University of Jyväskyla in Finland (see Kettunen, Lindberg, Nygaard, \& Kardal, Chapter 11) and, as of 2020, another summer school in social justice and career guidance at the Inland Norway University of Applied Sciences. VALA has mapped ten career guidance and counselling programmes in Denmark, Finland, Greenland, Iceland, Norway and Sweden against the curriculum model developed by the Network for Innovation in Career Guidance and Counselling in Europe (NICE) (Andreassen, Einarsdóttir, Lerkkanen, Thomsen, \& Wikstrand, 2019). The results show that all NICE core competences are represented in the curricula of the universities involved in the education of career professionals across the Nordic region. However, there is greater focus in some programmes on developing competences for individual career guidance, than on developing competences for working at organisational and societal levels.

Recently in 2019 the Nordic countries have established the Nordic Research Network on Transitions, Career and Guidance (NoRNet). The aim of the network is to increase research collaboration among the Nordic countries and to support international collaboration on research topics. There is also a working group which is seeking to develop a Nordic journal of career guidance.

\section{THE FOUR COS OF CAREER GUIDANCE IN NORDIC COUNTRIES}

In this section of the chapter we draw together some of the key insights from the other chapters in the book to provide an overarching characterisation of Nordic career guidance. We have described this characterisation as the four 'COs' of Nordic career guidance (context, community, co-construction and collaboration). The four COs provide a description of the key values and approaches that underpin career guidance in the Nordic countries.

As with any model or typology describing a complex social phenomenon that exists across multiple countries it is important to guard against simplifying differences within and across countries. The Nordic countries do not have a single approach to career and career guidance. This volume provides detail on all of the countries and highlights the different sectors and approaches that exist within each. However, it is 
hoped that the four COs can act as an organising framework for thinking about key concerns, trends and approaches within the field in the Nordic countries.

The four COs are:

- the acknowledgement of career and career guidance as embedded in context;

- community as important resource for career guidance;

- co-construction as the defining professional approach to career guidance; and

- collaboration between policy, research and practice across the Nordic countries as the usual way in which career guidance is developed and managed.

\section{Context}

We began this chapter with a discussion of the importance of context in understanding career and career guidance. Careers and career guidance emerge from context, they are at once psychological and social operating at the interface of the individual and society (Collin, 1997). Career guidance within the Nordic countries actively recognises the importance of context when helping people to develop their careers.

The need to recognise the Nordic context and to create a version of career guidance that is nationally and locally relevant is built into the heart of thinking about career guidance in the region. This means that practitioners and policymakers have been careful about importing international theories and models. Einarsdóttir, Björnsdóttir, and Lerkkanen (Chapter 12) explore the tension inherent in borrowing good ideas from other countries whilst attending to the local context in their chapter on career assessment instruments. They argue that emic approaches need to be used to validate instruments that may have originated in other cultures. This is illustrative of a wider urge to embedd career guidance practices within the Nordic context.

Other chapters in this book also pick up the importance of attending closely to the context within which career guidance is practiced and using this to inform its design and delivery. Alexander, Holm, Hansen, and Vahl (Chapter 5) show how career guidance needs to be adapted for the unique contexts in the Faroe Isles and Greenland, Vilhjálmsdóttir (Chapter 10) traces the way that the Icelandic career guidance profession emerged as part of a careful balancing of national and international influences and Fredriksen (Chapter 21) explores how practice needs to develop in response to the changed context of work with migrants.

As well as insisting that career guidance is embedded in Nordic cultures and contexts, there is also an interest in actively incorporating aspects of this context into the kinds of career guidance that are offered. Career guidance in the Nordic countries therefore actively recognises the importance of context and encourages individuals to notice the specific places and cultures in which they are pursuing their careers.

The way that context is recognised in careers work includes activities that allow for young people to experience education programmes and work before making choices to pursue them. This kind of experiential learning is central to the theories and approaches that underpin Nordic guidance (see Thomsen, 2014). This is 
exemplified in Chapter 17, where Skovhus and Thomsen identify taster programmes as a central component of career guidance activities for young people in schools across the Nordic region. Røise's contribution in Chapter 18 also highlights the way that learning about context through practical experiences is central to career education curricula in Norway. The provision of relevant labour market information as a key component of career guidance in the Nordic countries provides another example of career guidance actively fostering engagement with context (Alexander et al., Chapter 5; Launikari, Ahlroos, Hagen, \& Stefánsdóttir, Chapter 13).

\section{Community}

The second $\mathrm{CO}$ focuses on community as an important resource for career building. Nordic career guidance questions individualistic approaches and recognises that careers are built with others rather than alone. Individuals pursue their careers alongside others and as part of various kinds of community and collective. In response to this Nordic career guidance seeks to help people to develop collective responses to challenges and opportunities as well as individual responses.

The focus on community is exemplified by the 'career guidance in communities' approach which was developed in Denmark by Thomsen, Skovhus, and Buhl (2013). The aim of this model is to inspire practitioners and professionals to leave their offices and to bring career guidance into communities that might not identify or engage with it in the first instance. Whereas individualised approaches to career guidance encourage people to look within themselves to develop their careers, the community focused approaches found in the Nordic countries support individuals to draw on wider social and community resources. People and their careers are viewed as being part of the collective rather than atomised. Individuals' are encouraged to use the resources that they have in the communities that they are already part of and supported to build bridges with new communities e.g. through involving local business communities in career education activities (see Mordal, Buland, \& Mathiesen, Chapter 16).

Community based approaches can be seen in Chapter 21 where Fredriksen describes the development of a collective approach to the career counselling of refugees and immigrants arriving in Norway. In this example, career guidance is trying to both encourage the refugees to make use of their family and community resources as well as building bridges into wider Nordic society.

Another community-based approach is described in Chapter 22 by Thomsen, Rasmussen and Mariager-Anderson who explore the career guidance offered by trade unions. Trade unions provide an important form of community that brings together workers and provide a connection between individual career development and social and economic policy. The case study shows how, in addition to more traditional face-to-face conversations and group dialogues, career guidance practitioners are involved in interventions that support collective actions to build better career opportunities through structural and political work. 


\section{Co-Construction}

The third CO is co-construction which describes the way in which the Nordic career professional interacts with individuals in a non-hierarchical way and encourages people to work together and support each other. The idea of co-constructive career guidance challenges the idea of the professional as the repository of all of the answers and recognises that individuals are the experts in their own careers. Within such a conception, the role of the career professional is to support, facilitate and offer new frames of reference for career issues.

These kinds of progressive non-hierarchical forms of practice are closely aligned to the Nordic values that we have discussed earlier in the chapter. Political and cultural beliefs in democratic, egalitarian and non-hierarchical societies manifest in the practice of career guidance in the region. Recent years have seen these approaches come more to the fore with an increased interest in group guidance methodologies, career guidance in communities (Thomsen, 2012), career guidance in social media (Kettunen, 2017), listening to the voices of users more carefully in the development of career guidance services (Plant \& Haug, 2018) and network building as way of bringing people together, facilitating sharing processes and establishing supportive environments that can endure beyond the initial intervention.

The idea of co-construction within the wider career guidance literature is typically focused on the relationship that practitioners build with their clients in counselling environments (e.g. Brott, 2016; Maree \& Di Fabio, 2018) or their students in group and educational settings (Cohen-Scali \& Pouyaud, 2019; Kuijpers \& Meijers, 2017). This kind of non-hierarchal practice is an important aspect of Nordic career guidance. However, the Nordic conception of co-construction goes beyond this to recognise the need to co-construct systems and policies and to co-design the service itself.

Within the Nordic states it is common to include stakeholders and users in the development of policy as is illustrated in the example of the National Dialogue Forum in Denmark (Jensen, Chapter 8). A strong example of co-construction at the level of service design can be found in the Finnish One-Stop Guidance Centres discussed by Kettunen and Felt in Chapter 20. The development of the One-Stop Guidance Centres used the 4P approach (private-public-people-partnership) (Ng, Wong, \& Wong, 2013) to involve service users in the design and development of the centres. The 4P approach values bottom-up participatory strategies and places user engagement at the centre of service design.

Kettunen et al. (Chapter 11) expand the idea of co-construction to 'co-careering'. They highlight that the integration of modern technologies in career services has created a shift in guidance locus from being supplier-driven and bound by time and space to user-driven and happening everywhere and all the time (Kettunen, Sampson, \& Vuorinen, 2015). As a concept co-careering refers to online space where shared expertise and meaningful co-construction of career issues take place among community members (Kettunen, 2017). The practitioner is no longer in control of the process, but is now a participant in a process. Barnes, La Gro, and Watts (2010) 
described this shift as a progression from career guidance being led by the provider to it being led by the user. Furthermore, it is a way to think about the kind of stance that professionals need to take in engaging in and contributing to this kind of coconstructive approach within the online environment.

\section{Collaboration}

Finally, Nordic guidance is defined by a range of collaborative relationships that exist within the field. Guidance exists as a collaboration between multiple actors. Policymakers set the framework for it to happen, researchers shape and evaluate it, practitioners operationalise it and innovate, and clients and learners participate in it. This multi-actor nature of career guidance applies to its operation in all countries and parts of the world, although it is often ignored in academic commentaries on the field. What is distinctive about the Nordic career guidance field is that the contributions of the variety of actors are acknowledged and the relationship between the actors is characterised by collaboration and co-operation. Furthermore, this collaboration rests on the ideal of democratisation of both knowledge production and policymaking processes in the career guidance field.

In Chapter 8, Jensen looks at the introduction of guidance reforms in Denmark over the last twenty years. He argues that when these reforms worked best there were strong collaborative mechanisms available through the National Dialogue Forum and a clear relationship between policy, practice and research.

Finland also has a long history of good collaboration between the educational and employment sector regarding career guidance. In Chapter 9, Toni and Vuorinen describe the developments in lifelong guidance in Finland and provide an example of cross-ministerial collaboration and collaborations between national and regional government. So far, this has resulted in the One-Stop Guidance Centre model described in Chapter 20 by Kettunen and Felt, which reflects the ideas of New Public Governance (Osborn, 2010) and has a strong focus on collaboration and horizontal ties between individuals and agencies.

Recent developments in Norway have also showcased the close collaboration between research, policy and practice in relation to the development of a national framework for quality in career guidance. Kompetence Norge (Skills Norway) has facilitated a process of collaboration that steps up the usual approach to policy development through consultative processes. Through seminars involving three subject groups with practitioners from different sectors, researchers and policy makers from different organisations have worked together to develop a national quality framework for career guidance across all sectors. So far, this has resulted in a national report on four key themes, quality, ethics, competence standards and career learning (Haug et al., 2019a).

Poulsen and Buland (Chapter 15) explore an approach to collaboration between teachers, careers professionals and researchers and supported by trade unions and employers. They describe a process of developing career education activities and 
recommendations through the facilitation of research circles. Poulsen and Buland analyse the development of practice through research circles as a process of cogenerative learning and argue that this approach is rooted in the Nordic tradition of participatory action research.

Another important dimension of Nordic collaboration is the collaboration between actors in different Nordic countries. Cross-Nordic collaborations are illustrated by Kettunen et al. (Chapter 11). This chapter discusses an international course that has been jointly developed by practitioners and researchers from a range of Nordic countries to increase career practitioners' capacity in ICT (Kettunen, 2017). Other chapters in this volume (e.g. Chapters 4, 5, 12, 13 and 15) also demonstrate the lively culture of cross-Nordic collaboration that exists.

\section{ABOUT THE VOLUME}

\section{Content of the Volume}

The book is structured in three parts which follow this introductory chapter. Part 1 discusses the systems and policies that are used to organise career guidance across the Nordic region. Part 2 focuses on the profession, professional development and practitioner competences. Part 3 explores the range of practices that can be found in the Nordic countries.

Part 1 begins with Bakke's discussion, in Chapter 2, of the way in which the concept of career fits into the Nordic context. She argues that work, and therefore career, are central concerns in the Nordic model and Nordic culture, and that welfare is organised to ensure maximum participation in work and equal access to employment. In Chapter 3, Hooley explores the way in which those outside of the Nordic region see Nordic work, education and career guidance. Chapter 4, focuses on the issue of gender and gender equality, with Schulstok and Wikstrand examining how different ideas about gender politics across the region shape career thinking and career guidance. In Chapter 5, Alexander, Holm, Hansen and Motzfeldt Vahl focus on the development of career guidance in the self-governing Nordic regions of the Faroe Isles and Greenland. In Chapter 6, Kjærgård uses Foucault's analytical tools to explore and examine the development of career guidance historically and contextually. Chapters 7,8 and 9 look at policy developments in different Nordic countries. Lovén, Jensen and Toni and Vuorinen respectively describe the policy environments for career guidance in Sweden, Denmark and Finland.

Part 2 focuses on the career guidance profession. It begins, in Chapter 10, with Vilhjámsdóttir's history of the Icelandic guidance profession. She outlines four key elements of the history of guidance in Iceland, describing them as international cooperation, policy and legislation, the professional association and the education and training of school counsellors. Vilhjámsdóttir, argues that these four elements are needed in the making of a guidance profession in a small country like Iceland. In Chapter 11, Kettunen, Lindberg, Nygaard and Kardal describe the development of 
a cross-Nordic course designed to engage professionals in the use of information communication technologies (ICT) in guidance and counselling. In Chapter 12, the use of career assessments in the Nordic countries is discussed by Einarsdóttir, Björnsdóttir and Lerkkanen. Chapter 13, sees Launikari, Ahlroos, Hagen and Stefánsdóttir discuss how Nordic guidance professionals can support the international mobility of learners. In Chapter 14, Haug argues that there are many different ways to understand quality in career guidance in Norwegian schools. Part 2 finishes with a chapter from Poulsen and Buland (Chapter 15) where they discuss how collaborative research processes can facilitate professional learning and development in career guidance and counselling.

The final part focuses on the range of different practices that comprise career guidance across the Nordic countries. In Chapter 16, Mordal, Buland and Mathiesen present the findings from an exploratory study of career guidance and career learning in primary schools in Norway. Chapters 17 and 18 continue to focus on schools, first with Skovhus and Thomsen exploring the participation of lower secondary students in taster programmes in Denmark and then with Røise discussing the rationale underpinning the curriculum in the Norwegian subject Educational Choice. In Chapter 19, Jochumsen, describes the challenges of the digital transformation of analogue career guidance tools and examines how they are used. Chapter 20 sees Kettunen and Felt describe Finnish efforts to introduce and expand the service model known as the 'one stop guidance centre' as a tool for youth guarantee implementation. In Chapter 21, Fredriksen addresses the need for a more collective approach to the career counselling of refugees and immigrants arriving in the Nordic countries. In Chapter 22, Thomsen, Mariager-Anderson and Rasmussen examine the role of career guidance provided by trade unions for their members and the ways in which this guidance contributes to people's plans for and access to funds for competence development, adult education and further training. In the last chapter of the book (Chapter 23), Bakke, Barham and Plant argue that older people have distinctive career guidance needs. Drawing on research with Norwegian women they identify the characteristics of older people and their largely unmet guidance needs.

\section{Using This Volume}

This volume shares insights from the Nordic countries with everyone who takes an interest in developing practice, policy and research in career guidance. Career guidance has been a central component of Nordic welfare societies for many decades and the authors of the chapters in this volume offer insight into the organisation, policy and practice in the Nordic countries. We have pulled some insights together and used them to coin the four CO's of career guidance which we hope can act as an organising framework for thinking about key concerns within the field in the Nordic countries and beyond and as such make a contribution to the wider international community of career development for inspiration, discussion, critique and development. 
We hope that the volume will be useful to policymakers, researchers, students and practitioners in the Nordic countries. The research presented in this book reveals the Nordic states to be a natural laboratory for career guidance where multiple initiatives and experiments are being tried alongside longstanding practices and approaches. We have already discussed the strong tradition of cross-Nordic collaboration that exists in the careers field, we believe that this is one of the region's strengths, and hope that the material presented here can support this tradition of mutual learning and collaboration.

We also hope that this book will be of interest to those outside of the Nordic countries. Although this book is inspired by a need to recognise the local and cultural specificity of career and career guidance, we are also strongly internationalist in our approach. The book hopefully shows that the Nordic region has much to offer the wider world of career guidance, but we are also keen to learn from other places and engage in ongoing cooperation and sharing. The volume challenges the idea that a single theory or practice can be implemented across the world and champions the idea that a recognition of the cultural, political, economic and educational context is essential to underpin effective career guidance. We hope that this inspires ongoing dialogue between those interested in career guidance across the world and fosters a spirit of mutual, non-hierarchical sharing, co-operation and inspiration.

\section{BUILDING ON THE PRESENT, SHAPING THE FUTURE}

Before we finish this introduction, we would like to briefly look to the future of Nordic career guidance. To do this we want to reflect on discussions that we had with a wide range of experts at a workshop we organised on career guidance in the Nordic countries at the IAEVG conference in Göteborg in 2018. The workshop brought together around 50 participants from the Nordic countries and beyond to engage in dialogue about the past, present and future of Nordic guidance.

Participants described the landscape of career guidance in their countries and it became evident that the Nordic countries are all at different stages in the policy cycle. Some are witnessing increased interest in career guidance, others decreased interest. They also described a range of weaknesses in policy and provision across the Nordic countries. Participants reported that policy initiatives are often poorly implemented and rarely evaluated. They noted that national career guidance systems are rarely lifelong and tend to be organised on a sectoral basis and targeted at different age groups. They also bemoaned the fact the Nordic countries were often reluctant to promote innovative and successful career guidance initiatives internationally.

Workshop participants were clear that lifelong guidance should be seen as central to Nordic states' strategies on lifelong learning, labour force development and social equity. At the heart of such strategies should be high quality career guidance professionals and a common language that supports this profession to work crosssectorally. They also emphasised the importance of building on the tradition of community, professional and user participation in the development of policy and 
practice. Finally, the participants also discussed the importance of building on and extending the tradition of trans-Nordic co-operation on career guidance.

The chapters presented in this book build on and extend the description of the problems and opportunities that we identified in the IAEVG workshop. It is not a manifesto and we do not aim to present a set of 'demands'. However, we believe that the evidence presented here suggests that high quality, lifelong guidance should be at the heart of the Nordic model. There is much to be celebrated in the forms of career guidance that already exist in the Nordic countries and which we have summarise through the four COs. But, as we look to the future, we would hope that career guidance becomes more centrally embedded into policy and that policy support for the field across the region becomes more consistent and less prone to the whims of different governments. Career and career guidance needs to be viewed as a lifelong, cross-sectoral endeavour built on professionalism and evidence. All stakeholders should be involved in the design and development of career guidance services and practitioners, policymakers and researchers should be in the habit of sharing ideas with their colleagues across the region and beyond. This kind of vision of the future of guidance would require a big shift in policy and practice. The Nordic countries provide an ideal environment for such a shift to take place.

We hope that this book will be a step forwards into this future by stimulating dialogue, collaboration and debate across the Nordic countries and beyond.

\section{REFERENCES}

Andersen, L. P., Kjeldgaard, D., Lindberg, F., \& Östberg, J. (2019). Nordic branding: An odyssey into the Nordic myth market. In S. Askegaard \& J. Östberg (Eds.), Nordic consumer culture (pp. 213-238). Cham: Palgrave Macmillan.

Andreassen, I. H., Einarsdóttir, S., Lerkkanen, J., Thomsen, R., \& Wikstrand, F. (2019). Diverse histories, common ground and a shared future: The education of career guidance and counselling professionals in the Nordic countries. International Journal for Educational and Vocational Guidance, 19(3), 411-436. doi:10.1007/s10775-018-09386-9

Antikainen, A. (2006). In search of Nordic model in education. Scandinavian Journal of Educational Research, 50(3), 229-243. doi:10.1080/00313830600743258

Alexander, R. (2018). Social justice and geographical location in career guidance. In T. Hooley, R. G. Sultana, \& R. Thomsen (Eds.), Career guidance for social justice: Contesting neoliberalism (pp. 77-91). London: Routledge.

Alexander, R., \& Hooley, T. (2018). The places of careers: The role of geography in career development. In V. Cohen-Scali, J. Rossier, \& L. Nota (Eds.), New perspectives on career counseling and guidance in Europe (pp. 119-130). Cham: Springer.

Archer, C., \& Joenniemi, P. (2017). The Nordic peace. London: Routledge.

Arulmani, G. (2016). Contexts and circumstances: The cultural preparation process approach to career development. In M. McMahon (Ed.), Career counselling: Constructivist approaches (pp. 97-108). London: Routledge.

Barnes, A., La Gro, N., \& Watts, A. G. (2010). Developing e-guidance competencies: The outcomes of a two-year European project to transform the professional development of career guidance practitioners. Career research and development. The NICEC Journal, 25, 26-32.

Bergmo-Prvulovic, I. (2018). Conflicting perspectives on career. Implications for career guidance and social justice. In T. Hooley, R. G. Sultana, \& R. Thomsen (Eds.), Career guidance for social justice: Contesting neoliberalism (pp. 143-158). London: Routledge. 


\section{E. H. HAUG ET AL.}

Brott, P. E. (2016). The storied approach to career co-construction with an older female client. In L. A. Busacca \& M. C. Rehfuss (Eds.), Postmodern career counseling: A handbook of culture, context, and cases (pp. 147-162). Alexandria, VA: American Counseling Association.

Browning, C. S. (2007). Branding nordicity: Models, identity and the decline of exceptionalism. Cooperation and Conflict, 42(1), 27-51.

Cohen-Scali, V., \& Pouyaud, J. (2019). A career education approach based on group dialogues to help adolescents and emerging adults in their self construction. In J. Maree (Ed.), Handbook of innovative career counselling (pp. 405-424). Cham: Springer.

Collin, A. (1997). Career in context. British Journal of Guidance \& Counselling, 25(4), 435-446.

Dahl, H. M. (2012). Neo-liberalism meets the Nordic welfare state-Gaps and silences. NORA-Nordic Journal of Feminist and Gender Research, 20(4), 283-288.

Darmon, I., \& Perez, C. (2011). 'Conduct of conduct' or the shaping of 'adequate dispositions'? Labour market and career guidance in four European countries. Critical Social Policy, 31(1), 77-101.

ELGPN [European Lifelong Guidance Policy Network]. (2014). Lifelong guidance policy development: Glossary (ELGPN Tools No. 2). Jyväskylä, Finland.

Gradén, L. (Ed.). (2016). Performing Nordic heritage: Everyday practices and institutional culture. London: Routledge.

Greve, B. (2007). What characterise the Nordic welfare state model. Journal of Social Sciences, 3(2), 43-51.

Grendstad, G. (2001). Nordic cultural baselines: Accounting for domestic convergence and foreign policy divergence. Journal of Comparative Policy Analysis: Research and Practice, 3(1), 5-29.

Grey, C. (1994). Career as a project of the self and labour process discipline. Sociology, 28, 479-497.

Halvorsen, R., \& Hvinden, B. (2015). New policies to promote youth inclusion: Accommodation of diversity in the Nordic welfare states. Copenhagen: Nordic Council of Ministers.

Haug, E. H., Holm-Nordhagen, A., Thomsen, R., Schulstok, T., Engh, L. W., Gravås, T. F., ... Gaarder, I. E. (2019a). Nasjonalt kvalitetsrammeverk for karriereveiledning. Faglig forslag til områdene etikk, karrierekompetanse og kompetansestandarder [National Quality Framework for career guidance. Professional suggestion for ethics, career competence and competence standards]. Oslo: Kompetence Norge [Skills Norway]. Retrieved from https:/www.kompetansenorge.no/Karriereveiledning/ kvalitet-i-karriereveiledning/

Haug, E. H., Plant, P., Valdimarsdóttir, S., Bergmo-Prvulovic, I., Vuorinen, R., Lovén, A., \& Vilhjálmsdóttir, G. (2019b). Nordic research on educational and vocational guidance: A systematic literature review of thematic features between 2003 and 2016. International Journal for Educational and Vocational Guidance, 19, 185-202. doi:10.1007/s10775-018-9375-4

Hooley, T., Sultana, R. G., \& Thomsen, R. (2018). The neoliberal challenge to career guidance: Mobilising research, policy and practice around social justice. In T. Hooley, R. G Sultana, \& R. Thomsen (Eds.), Career guidance for social justice: Contesting neoliberalism (pp. 1-28). London: Routledge.

Hvid, H. S., \& Falkum, E. (2019). Work and wellbeing in the Nordic countries: Critical perspectives on the world's best working lives. New York, NY: Routledge.

Jungar, A. C., \& Jupskås, A. R. (2014). Populist radical right parties in the Nordic region: A new and distinct party family? Scandinavian Political Studies, 37(3), 215-238.

Kettunen, J. (2017). Career practitioners' conceptions of social media and competency for social media in career services (Dissertation, Studies, 32). University of Jyväskylä, Finnish Institute for Educational Research, Jyväskylä, Finland.

Kettunen, J., Sampson Jr., J. P., \& Vuorinen, R. (2015). Career practitioners' conceptions of competency for social media in career services. British Journal of Guidance \& Counselling, 43(1), 43-56. doi: $10.1080 / 03069885.2014 .939945$

Kuijpers, M., \& Meijers, F. (2017). Professionalising teachers in career dialogue: An effect study. British Journal of Guidance \& Counselling, 45(1), 83-96.

Kvist, J., \& Greve, B. (2011). Has the Nordic welfare model been transformed? Social Policy and Administration, 45(2), 146-160. doi:10.1111/j.1467-9515.2010.00761.x

Marklund, C. (2017). The Nordic model on the global market of ideas: The welfare state as Scandinavia's best brand. Geopolitics, 22, 623-639. doi:10.1080/14650045.2016.1251906 
Maree, J., \& Di Fabio, A. (2018). Integrating personal and career counseling to promote sustainable development and change. Sustainability, 10(11), 4176. doi:10.3390/su10114176

Mjøset, L. (2011). Nordic political economy after financial deregulation: Banking crises, economic experts, and the role of neoliberalism. In L. Mjøset (Ed.), The Nordic varieties of capitalism (pp. 365-420). Bingley: Emerald Group Publishing Limited.

Network for Adult Learning (NVL). (2015) Guidance in validation within the Nordic region - Challenges and opportunities (NVL report). Oslo: NVL.

Network for Adult Learning (NVL). (2017). Samordning av vägledningen $i$ de nordiska länderna, Färöarna, Grönland och Aland [Coordination of guidance in the Nordic countries, The Faroe Islands, Greenland and Aalandland] (NVL report). Oslo: NVL.

Nielson, P. (2016). Working life in the Nordic region: Challenges and proposals. Copenhagen: Nordic Council of Ministers.

Ng, S. T., Wong, J. M. W., \& Wong, K. K. W. (2013). A public private people partnerships (P4) process framework for infrastructure development in Hong Kong. Cities, 31, 370-381. doi:10.1016/j. cities.2012.12.002

OECD [Organisation for Economic Co-operation and Development]. (2004). Career guidance and public policy: Bridging the gap. Paris: OECD.

Osborne, S. P. (Ed.). (2010). The new public governance: Emerging perspectives on the theory and practice of public governance. London: Routledge.

Plant, P. (2003). The five swans: Educational and vocational guidance in the Nordic countries. International Journal for Educational and Vocational Guidance, 3(2), 85-100.

Plant, P., \& Haug, E. H. (2018). Unheard: The voice of users in the development of quality in career guidance services. International Journal of Lifelong Education, 37(3), 372-383.

Plant, P., \& Thomsen, R. (2011). Career guidance in Denmark: Social control in a velvet glove. Orientación y Sociedad, 11.

Prøitz, T. S., \& Aasen, P. (2017). Making and re-making the Nordic model of education. In P. Nedergaard \& A. Wivel (Eds.), The Routledge handbook of Scandinavian politics (pp. 213-228). London: Routledge.

Ribeiro, M. A., \& Fonçatti, G. D. O. S. (2018). The gap between theory and context as a generator of social injustice: Seeking to confront social inequality in Brazil through career guidance. In T. Hooley, R. G. Sultana, \& R. Thomsen (Eds.), Career guidance for social justice: Contesting neoliberalism (pp. 193-208). London: Routledge.

Ryner, J. M. (2007). The Nordic model: Does it exist? Can it survive? New Political Economy, 12(1), 61-70.

Sandemose, A. (1999[1933]). En flyktning krysser sitt sport: Fortellingen om en morders barndom [A fugitive crosses his tracks: The story of a murderers childhood]. Oslo: Aschehoug \& Co.

Savickas, M. L. (2012). Life design: A paradigm for career intervention in the 21st century. Journal of Counseling \& Development, 90(1), 13-19.

Strang, J. (2015). Nordic political and economic cooperation: Context, history and outlook. Retrieved from http://www.asean-aemi.org/wp-content/uploads/2015/11/AEMI-Connectivity-Singapore_ JohanStrang.pdf

Sultana, R. G. (Ed.). (2017a). Career guidance and livelihood planning across the Mediterranean: Challenging transitions in South Europe and the MENA region. Rotterdamn, The Netherlands: Sense Publishers.

Sultana, R. G. (2017b). Career guidance in multicultural societies: Identity, alterity, epiphanies and pitfalls. British Journal of Guidance \& Counselling, 45, 451-462.

Thomsen, R. (2012). Career guidance in communities. Aarhus: Aarhus University Press.

Thomsen, R., Skovhus, R. B., \& Buhl, R. (2013). At vejlede i fallesskaber og grupper [Guidance in communities and groups]. Valby: Schultz.

Thomsen, R. (2014). A Nordic perspective on career competences and guidance: Career choices and career learning. NVL \& ELGPN concept note. Oslo: Nordiskt Nätverk för Vuxnas Lärande (NVL).

Trotter, S. R. (2015). Breaking the law of Jante. Myth and Nation, 23. 


\section{E. H. HAUG ET AL.}

Tägil, S. (Ed.). (1995). Ethnicity and nation building in the Nordic world. Carbondale, IL \& Edwardsville, IL: Southern Illinois University Press.

Vuorinen, R., \& Leino, L. (2009). Expected outputs/outcomes of guidance services for adults in the Nordic countries. Oslo: Nordiskt Nätverk för Vuxnas Lärande (NVL).

Zelloth, H. (2009). In demand: Career guidance in EU neighbouring countries. Luxembourg: Office for Official Publications of the European Communities.

Watts, A. G. (2014). Cross-national reviews of career guidance systems: Overview and reflections. Journal of the National Institute for Career Education and Counselling, 32(1), 4-14. 